ORIGINAL ARTICLE

AFRICAN JOURNAL OF CLINICAL AND EXPERIMENTAL MICROBIOLOGY MAY 2015 ISBN 1595-689X AJCEM/1512

COPYRIGHT 2015 http://dx.doi.org/10.4314/ajcem.v16i2.4

http://www.ajol.info/journals/ajcem

VOL16 No.2

AFR. J. CLN. EXPER. MICROBIOL. 16(1): 67-72

\title{
ANTIFUNGAL SUSCEPTIBILITY PROFILES AND RISK FACTORS OF VAGINAL CANDIDIASIS AMONGST FEMALE UNIVERSITY STUDENTS IN SOUTHWEST REGION, CAMEROON
}

\author{
Ane-Anyangwe, I. ${ }^{1 ;}$ Meriki, H. D. ${ }^{1,}{ }^{2}$, Silum$^{1}$ S. P.;Nsongomanyi, F. R. ${ }^{1}$ and Zofou, D. ${ }^{3}$ \\ ${ }^{1}$ Department of Microbiology and Parasitology, Faculty of Science, University of Buea, Cameroon; ${ }^{2 M i c r o b i o l o g y ~ U n i t, ~ B u e a ~}$ \\ Regional Hospital, SW Region, Cameroon; ${ }^{3}$ Biotechnology Unit, Faculty of Science, University of Buea, Cameroon; \\ *Correspondence: Ane-Ayangwe Irene, Ph.D., Department of Microbiology and Parasitology, Faculty of Science, University of \\ Buea, Tel: +23751274276 email: ianyangwe@yahoo.com

\section{RUNNING TITLE: ANTIFUNGAL SUSCEPTIBILITY PROFILES AND RISK FACTORS OF VAGINAL CANDIDIASIS} \\ AMONGST FEMALE UNIVERSITY STUDENTS
}

\begin{abstract}
ABSRACT
Vaginal candidiasis (VC) is second to bacterial vaginitis, as the most common opportunistic mucosal infection that affects large numbers of otherwise healthy women of childbearing age. The incidence of VC is significantly modified by dressing patterns and aberrant health-care practices. Contemporary young women often shift their preference from skirt to trousers and leggingswhich also coincides with a rise in auto-medication and over-the-counter drugs phenomena in our communities. These could result in increased occurrence of vaginal candidiasis infection and antifungal drug resistance. This was a cross-sectional study conducted between March 2011 and August 2011 among150 female students(aged 17-29 years) of the University of Buea.Socio-demographics information, risk factors and clinical symptoms were gotten through a standard questionnaire. Vaginal swabs were collected from each participant and cultured on Sabouraud'sdextrose agar supplemented with chloramphenicol (SDA-CAF). Identification and antifungal susceptibility testing was performed following standard microbiological procedures. Of the 150 participants who submitted vaginal swabs, yeasts was isolated in 98 (65.3\%). Of the 98 yeasts isolates, $73.5 \%$ were Candida species, mainly $C$. albicans $(65.3 \%)$. Overhalf $(64.7 \%)$ ofstudyparticipantshadapreferencefortrousers,however, this attitude was not significantly associated $(p=0.559)$ with candidiasis.Previous episodes of vaginal infection and treatment for candidiasis were significantly associated with VC $(\mathrm{p}=\mathbf{0 . 0 0 4 )}$. Antifungal susceptibility results showed a high resistance to fluconazole $(82.0 \%)$, nystatin $(80.0 \%)$ and ketoconazole $(72.0 \%)$, while clotrimazole $(50.0 \%)$ was the most activeantifungal drug. There was a high prevalence of VC in this study population with previous vaginal infectionbeing important risk factor for reoccurrence. Clotrimazole was the drug of choice in the treatment of VC in this population.
\end{abstract}

Key words: vaginal candidiasis, risk factors, antifungal susceptibility profiles

\section{PROFILS DE SENSIBILITE AUX ANTIFONGIQUES ET FACTEURS DE RISQUE DE CANDIDOSE VAGINALE CHEZ LES ETUDIANTES UNIVERSITAIRES AU SUD-OUEST DU CAMEROON}

\section{TITRE COURANT:PROFILS DE SENSIBILITE AUX ANTIFONGIQUES ET FACTEURS DE RISQUE DE CANDIDOSE VAGINALE CHEZ LES ETUDIANTES UNIVERSITAIRES}

La candidose vaginale $(\mathrm{CV})$ est la deuxième infection opportuniste de la muqueuse la plus fréquente (après la vaginite bactérienne) qui affecte un grand nombre de femmes en âge de procréer. L'incidence de la CV est affectée de façon significative par certaines habitudes vestimentaires et pratiques de soins de santé « aberrante »s. Chez les jeunes femmes contemporaines, les pantalons et leggings sont de plus en plus préférés aux jupes, ce qui coïncide aussi avec une augmentation du phénomène d'automédication dans nos communautés. Ces deux facteurs pourraient entraîner une augmentation de la prévalence de l'infection à Candida vaginale et la résistance aux antifongiques. La présente étude transversale a été menée entre Mars et Août 2011 portait sur 150 étudiantes âgées de 17 à 29 ans, à l'Université de Buea (Cameroun). Elle avait pour objectifs majeurs d'évaluer les profils de sensibilité aux antifongiques ainsi que les facteurs de risque de candidose vaginale chez les étudiantes universitaires. Les données sociodémographiques, informations sur les facteurs de risque et les symptômes cliniques ont été explores à l'aide d'un questionnaire semi-structuré. Des spécimens vaginaux ont été prélevés dans chaque participante et soumis à une culture sur le dextrose gélose de Sabouraud supplémenté par le chloramphénicol (SDA-CAF). Les tests d'identification et de sensibilité antifongique ont été réalisés suivant des procédures microbiologiques standard. Parmi les 150 participants qui ont soumis des prélèvements vaginaux, des levures ont été isolées de 98 personnes $(65,3 \%)$. Sur les 98 levures isolées, 73,5\% étaient des espèces de Candida, principalement $C$. albicans $(65,3 \%)$. Plus de la moitié des participants $(64.7 \%)$ ont exprimé des préférences pour les pantalons et autres styles vestimentaires émergents. Cependant, de telles attitudes n'ont pas paru statistiquement associées à l'occurrence des candidoses au sein de la population ciblée $(p=0.559)$. Des précédents épisodes d'infection vaginale et le traitement de la candidose reportés par les participantes étaient significativement associés à $\mathrm{CV}(\mathrm{p}=0,004)$. Les résultats de sensibilité antifongiques ont montré une grande résistance au Fluconazole $(82,0 \%)$, Nystatine $(80,0 \%)$ et Kétoconazole $(72,0 \%)$, tandis que le Clotrimazole $(50,0 \%)$ était le médicament antifongique le plus actif. Il y avait une forte prévalence de CV dans cette population d'étude avec infection vaginale précédente étant facteur de risque important pour la répétition. Le Clotrimazole s'est avéré comme étant le médicament de choix dans le traitement des CV dans cette population, malgré la forte résistance.

Mots clés: Candidose Vaginale, facteurs de risque, les profils de sensibilité aux antifongiques 


\section{INTRODUCTION}

Bacterialvaginitis, vaginal candidiasis and trichomoniasis are responsible for $90 \%$ of the cases of vaginal infections (1). Vaginal candidiasisissecond to bacterial vaginitis(2), as the most common opportunistic mucosal infection that affects large numbers of otherwise healthy women of childbearing age $(3,4)$. VC usually occurs when there is overgrowth of the fungus, Candida, present in the body as a normal commensal(5)whichis characterized by curd-like vaginal discharge and itches(6). Up to $75 \%$ of reproductive-age women are infected with $\mathrm{VC}$ at least once $(6,7)$ and about half of these women experience more than one recurrence, and $5 \%-8 \%$ have multiple episodes each year(7). In addition to discomfort and the costs associated with medication and health care visits, several prospective studies have suggested that VC may increase a woman's risk of contracting other sexually transmitted diseases such ashuman immunodeficiency virus(9).

Although VC in pre-menarchal and post-menopausal women is rare, there are several endogenous and exogenousfactors that predispose menarchal women to acute VC; including several hormonal modulations associated with pregnancy, luteal phase of the menstrual cycle, oral contraceptive use, hormone replacement therapy and non-hormonal factors such as antibiotic use and uncontrolled diabetes mellitus(10).

Dressing pattern such as tight clothing and synthetic underwear have been reported to increase the risk of candidiasis(10, 11)although other investigatorshave contrary reports $(12,13)$. In recent times, young women often shift their preference from skirt to trousers/leggings or tight under wears and this also coincides with a rise in auto-medication and over-the counter drugs phenomena in our communities. Access to over-the-counter medications allows women to selfdiagnose and treat vaginal symptoms (5). These and other possible risk behaviours could result in the increase prevalence of vaginal candidiasis and antifungal drug resistant.Consequently, the present study sought to investigate the prevalence of $\mathrm{VC}$, determine the possible risk factors and antifungal sensitivity patternsamong female students of reproductive age at the University of Buea.Such data will provide important information in developing effective strategies for the prevention, control and possible treatment options for $\mathrm{VC}$.

\section{MATERIAL AND METHODS}

\section{Study design and population}

This cross-sectional study was conducted between March 2011 and August 2011. The study population comprised female students of child-bearing age (17-29 years) enrolled in both postgraduate and undergraduate programs at the University of Buea, who gave their consent to participate in the study. Questionnaires were administered to obtain information on demographics, risk factors and medical history of VC.

Sample collectionSamples were collected as previously reported (15). Briefly, each participant was given a sterile swab stick and instructed to self-collectan early morning vaginal swab before bath by introducing the sterile swab into vaginal area and gently moving the swab by rotatingand allowing for some time to absorbed vaginal discharge. The samples were delivered within 2 hours to Life Science teaching laboratory of the University of Buea for analysis.

Culture and Microscopy Samples were inoculated on Sabouraud's dextrose agarsupplemented with chloramphenicol (SDA-CAF) (Plasmatec Laboratory Products LTD, UK). The plates were incubated aerobically at $37{ }^{\circ} \mathrm{C}$ for $24-48$ hours after which they were examined for raised, creamcoloured, opaque, yeast smelling colonies. Morphologically distinct colonies from each culture were sub-culturedand stored on SDA slant for subsequent identification.Vaginal swabs were rolled onto slides, air dried and Gram stained following standard microbiological procedures. The slides were viewed with light microscope at $100 \mathrm{X}$ for yeast morphology. Wet mount preparations were prepared by placing the swab stick into $0.5 \mathrm{ml}$ sterile normal saline and mixed vigorously. A drop of the suspension was then placed on a clean labelled slide, covered with a cover slip, and carefully examined under a microscope using the $40 \mathrm{X}$ objective to observe yeast morphology.

\section{Identification and antifungal susceptibility testing}

Positive cultures were further tested for germ tube formation (evidence for C. albicans). Discrete colonies were inoculated in bovine serum and incubated at 35$37{ }^{\circ} \mathrm{C}$ for $2-3$ hours. The serum preparations were then transferred on slides and viewed under the microscope (10X and 40X objectives) for the presence of germinating blastospores or germ tube formation. A complete identification of yeast isolates was carried out usingAnalytical Profile Index for Candida (API Candida kit, BioMerieux SA) according to manufacturer's instructions.Antifungal sensitivity testing was performed only on Candida species isolates, using the modified Kirby-Bauer disc diffusion method on SDA as previously reported(16). The antifungal discs [potency] used included nystatin [100 IU], fluconazole [100 $\mu \mathrm{g}$ ], ketoconazole $[10 \mu \mathrm{g}]$ and clotrimazole [50 $\mu \mathrm{g}]$.

The data was recorded and analysed using descriptive analysis and Chi-square on SPSS Version 11.0 statistical software at 0.05 significance level. Ethical clearance for the study was obtained from the Regional Delegation of Public Health for the Southwest region.

\section{RESULTS}

Study population description and clinical presentationOne hundred and fifty female students, mean age 20.5 year (Range 17-29) were enrolled for the 
study, with $68 \%$ being symptomaticand $32 \%$ asymptomatic cases. The reported clinical symptoms included vaginal itches (57.3\%), abnormal vaginal discharge $(31.3 \%)$ and burning pain sensations(14\%).Over half $(64 \%)$ of the participants accepted to have had previous episodes of VC and among them half (48/96), sought for medical attention and VC was diagnosed by laboratory findings while the remainder were self-diagnosed. Of those who were self-diagnosed, 23 (47.9\%) reported to have taken automedication. A total of $64.7 \%$ of the study participants acknowledged preference for trousers while $49.3 \%$ preferred tight under wares. Majority (70\%) of the participants reported haverecently use antibiotics while $15.3 \%$ accepted have been on oral contraceptives.

Prevalence of Candida species in the study population

Microscopic examination of wet preparation showed presence of yeast cells in $48.7 \%$ (73/150) occurringmostly as single cells/bud (72.6\%), while the rest $(27.3 \%)$ presented as ovoid buds/pseudo-hyphae. A total of 85 of the samples (56.7\%) were positive by Gram stained smears while 98 (65.3\%) were identified by culture.Of the 98 positive cultures, $48 \%$ (47/98), $25.5 \%(25 / 98)$ and $26.5 \%$ (26/98) showed profuse, moderate and scanty growth respectively on SDA. Half (50\%) of the isolates produced germ tubes and hence were presumptively considered Candida species. Isolates were further identified with Analytical Profile Index for Candida species(API candida). Overall, based on germ tube identification test and the API candida test, $73.5 \%$ (72/98) of the isolates were identified as Candida species while $26.5 \%(26 / 98)$ of the isolates were noncandida species. The Candida species,includedC. albicans $(42.7 \%)$, C. tropicalis $(3.4 \%)$, C. glabrata(1.3\%) and C. krusei (0.7). Other yeast species identified were Saccharomyces cerevisiae (12.7\%) and Trichosporon species (4.7\%).(Table 1).

TABLE 1: PREVALENCE OF CANDIDA SPECIES AND OTHER YEAST SPECIES IN THE STUDY POPULATION

\begin{tabular}{|c|c|c|c|c|}
\hline Yeasts species & Germ tube test & API candida positive & $\begin{array}{l}\text { Total } \\
(\%)\end{array}$ & Total prevalence $(\%)$ \\
\hline C. albicans & 49 & 15 & $64(42.7)$ & \multirow{4}{*}{$\begin{array}{c}\text { Candida spp } \\
72 \text { (73.5) }\end{array}$} \\
\hline C. tropicalis & / & 05 & $05(3.4)$ & \\
\hline C. glabrata & / & 02 & $02(1.3)$ & \\
\hline C. krusei & / & 01 & $01(0.7)$ & \\
\hline Saccharomyces cerevisiae & / & 19 & $19(12.7)$ & \multirow[t]{3}{*}{$\begin{array}{l}\text { Other yeast } \\
26(26.5)\end{array}$} \\
\hline Trichosporon species & / & 07 & $07(4.7)$ & \\
\hline Total & 49 & 49 & $98(65.3)$ & \\
\hline
\end{tabular}

Antifungal susceptibility testingAntifungal susceptibility testing results was classified as susceptible, intermediateor resistant. Our results revealed that isolates were most susceptible to clotrimazole $50.0 \%(25 / 50)$. On the other hand, none of the isolates were susceptible to fluconazole and nystatin, although some isolates showed intermediate to fluconazole $(18.0 \%)$ and to and nystatin $(20.0 \%)$. Resistance to fluconazole,nystatinand ketoconazole were $(82 \%),(80 \%)$ and $(72 \%)$ respectively (Figure 1$)$.

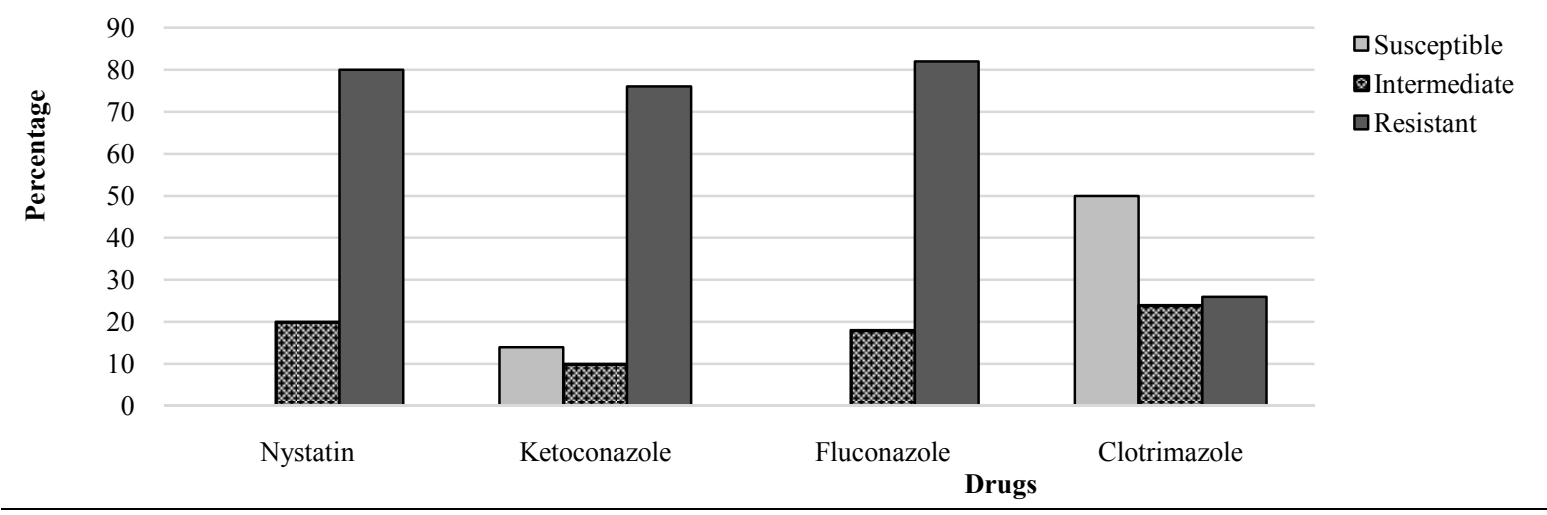

FIGURE 1: ANTIFUNGAL DRUG RESISTANT PROFILE OF CANDIDA ALBICANS ISOLATES 
Risk factors associated with vaginal candidiasis Although not significantly different, VC was higher among symptomatic (OR: 1.20, 95\% confidence interval [CI]: 0.59-2.45) than non-symptomatic subjects, in participants who preferred tight (OR: 1.37, 95\% CI: 0.69-2.69) than loose under wears, and also among those who had preference for trousers (OR: 1.23, 95\% CI: 0.61-2.47) than skirt outfit.
Similarly, use of oral contraceptives (OR: 1.25, 95\% CI: 0.48-3.28) and recent use of antibiotics (OR: 1.44, 95\% CI: 0.68-3.08) both increase the risk of vaginal candidiasis. Previous episodes of vaginal infection (OR: 2.79, 95\% CI: 1.38-5.64) was significantly associated $(p=0.004)$ with vaginal candidiasis. On the other hand previous treatment for VC (OR: 0.36, 95\% CI: 0.18-0.72) was protective against VC. (Table

2).

TABLE 2: PREVALENCE OF VAGINAL CANDIDIASIS AND ASSOCIATED RISK FACTORS

\begin{tabular}{|c|c|c|c|c|c|c|}
\hline \multirow[t]{2}{*}{ Parameters } & \multirow[t]{2}{*}{ Category } & \multirow[t]{2}{*}{$\begin{array}{l}\text { Overall prevalence } \\
\qquad(\%)\end{array}$} & \multicolumn{2}{|c|}{$\begin{array}{c}\text { Vaginal } \\
\text { Candidiasis, } \mathrm{n}(\%)\end{array}$} & \multirow[t]{2}{*}{$\begin{array}{l}\text { Odd ratios } \\
{[95 \% \mathrm{CI}]}\end{array}$} & \multirow[t]{2}{*}{ P-value } \\
\hline & & & Yes & No & & \\
\hline \multirow{2}{*}{$\begin{array}{l}\text { Presence of clinical signs } \\
\text { and symptoms }\end{array}$} & Yes & $102(68.0)$ & $68(66.7)$ & $34(33.3)$ & $1.20[0.59-2.45]$ & \multirow[t]{2}{*}{0.617} \\
\hline & No & $48(32.0)$ & $30(62.5)$ & $18(37.5)$ & 1 & \\
\hline \multirow{2}{*}{$\begin{array}{l}\text { Previous episodes of } \\
\text { vaginal infection }\end{array}$} & Yes & $96(64.0)$ & $72(75.0)$ & $24(25.0)$ & $2.79[1.38-5.64]^{*}$ & \multirow[t]{2}{*}{0.004} \\
\hline & No & $54(36.0)$ & $28(51.9)$ & $26(48.1)$ & 1 & \\
\hline \multirow{2}{*}{$\begin{array}{l}\text { Previously treated for } \\
\text { vaginal candidiasis }\end{array}$} & Yes & $72(48.0)$ & 37 (51.3) & $35(48.3)$ & $0.36[0.18-0.72]^{*}$ & \multirow{2}{*}{0.004} \\
\hline & No & $78(52.0)$ & $58(74.4)$ & $20(25.6)$ & 1 & \\
\hline \multirow[t]{2}{*}{ Under wares } & Tight & $74(49.3)$ & $51(68.9)$ & $23(31.1)$ & 1.37 [0.69-2.69] & \multirow[t]{2}{*}{0.363} \\
\hline & Loose & $76(50.7)$ & $47(61.8)$ & $29(38.2)$ & 1 & \\
\hline \multirow[t]{2}{*}{ Dressing outfit } & Trousers & $97(64.7)$ & $65(67.0)$ & $32(33.0)$ & $1.23[0.61-2.47]$ & \multirow[t]{2}{*}{0.559} \\
\hline & Skirts & $53(35.3)$ & $33(62.3)$ & $20(37.7)$ & 1 & \\
\hline \multirow[t]{2}{*}{ Douching } & Yes & $79(52.7)$ & $48(60.8)$ & $31(39.2)$ & $0.65[0.34-1.28]$ & \multirow[t]{2}{*}{0.216} \\
\hline & No & $71(47.3)$ & $50(70.4)$ & $21(29.6)$ & 1 & \\
\hline \multirow[t]{2}{*}{ Oral contraceptives } & Yes & $23(15.3)$ & $16(69.6)$ & $07(30.4)$ & $1.25[0.48-3.28]$ & \multirow[t]{2}{*}{0.644} \\
\hline & No & $127(84.7)$ & $82(64.6)$ & $45(35.4)$ & 1 & \\
\hline \multirow[t]{2}{*}{ Recent use of antibiotics } & Yes & $105(70.0)$ & $78(74.3)$ & $27(25.7)$ & $1.44[0.68-3.08]$ & \multirow[t]{2}{*}{0.342} \\
\hline & No & $45(30.0)$ & $30(66.7)$ & $15(31.1)$ & 1 & \\
\hline
\end{tabular}

\section{DISCUSSION}

This study investigated the prevalence of $\mathrm{VC}$, antifungal resistance profiles and possible risk factors among female students in the University of Buea. The overall prevalence of yeast species was $65.3 \%$.However, the prevalence of Candida species in this study was $48 \%$ with $C$. albicans having the highest prevalence $(42.7 \%)$ in conformity with prior studies(17, 4, 18).As previously demonstrated, C. albicansis the most predominant yeast species in the environment and hence occurs as a normal human vaginal flora. More so, its ability to form germ tube confers it survival abilities over other yeast species(19).

Generally, laboratory diagnosis of VC in resourcelimited settings like ours is accomplished most often with less a sensitive microscopic examination of fresh and grams stained smears of vaginal specimens. In this study the prevalence of yeast by microscopic examination of wet preparation was $48.7 \%$, which increased to $56.7 \%$ by microscopy of gram stained smears. The prevalence further increased to $65.3 \%$ by culture (20). Although culture 
improves diagnosis of $\mathrm{VC}$, this is not a common method of laboratory diagnosis in this setting and therefore, adequate characterisation of Candida albicans by microscopy remains challenging. Presumptive identification of $C$. albicansisolates can be achieved with germ tubes test and in this study up to $50 \%$ of the culture positive isolates were identified. Commercial identification test provide more sensitive and specific method for differentiating non-albicansCandida species. Three non-albicans species were identified (C. tropicalis, $C$. glabrata, C. krusei) and the two other yeast species (Saccharomyces cerevisiae and Trichosporon species) with API candida test kit.Unlike many previous findings which predominantly isolated Candida species and considered to be the main cause of VC (4, 18 ), our results revealed that $S$. cerevisiae and Trichosporon species could be responsible for causing VC since they were isolated from symptomatic subjects. In support of this findings, S. cerevisiae and rarely Trichosporon species(21)have also been isolated in vaginal infections and were assumed to be emerging pathogens isolated from fungal infections(22).

We also evaluated the antifungal susceptibility patterns of the Candida isolates to commonly prescribed and readily available drugs in the locality. Fifty per cent of Candida specieswere susceptible, while $24 \%$ were intermediate to a member of the azole group (clotrimazole), used in the study. Clotrimazoleis one of the reserved antifungal not frequently prescribed in the treatment of VC in this setting. Few (14\%) of the isolates were susceptible to ketoconazole and showedno susceptibility to fluconazole. VC is treated effectively with azole-based antifungal drugs(23), however, most of the isolates were found to be resistant to ketoconazole (76\%) andfluconazole (82\%). On the other hand, the high resistance observed in nystatin $(80 \%)$, (a polyene) could be blamed to the excessive use of this drug in the locality as topical ointment or suppository as a result of its availability and low cost.

As previously reported itching sensations, burning internal pain and cream white 'cheesy' discharge were the main reported symptoms with majority of the symptomatic participantshaving vaginal itches $(57.3 \%)(20)$.Among those who reported previous

\section{REFERENCES}

1. Adad SJ, de Lima R V., Sawan ZT, Silva ML, de Souza MA, Saldanha JC, et al. Frequency of Trichomonas vaginalis, Candida sp and Gardnerella vaginalis in cervical-vaginal smears in four different decades. Sao Paulo Med J. 2001;119(6):2005 . vaginal infections, self-diagnosis (50\%) and automedication $(47.9 \%)$ were common practices. This behaviour is prompted by the availability of overthe-counter drugs. There was no statistically significant difference in the prevalence of yeast among symptomatic and asymptomatic subjects. A good number of women are infected with VC without any significant discomfortand this may be as results of the fact symptoms of VC, such as vaginal itches, abnormal vaginal discharge and burning vaginal pains are very nonspecific (8).

Even though, not statisticallysignificant in this study, tight fitting garments, trousers and synthetic underwear have been previously reported to increase the risk of VC (12) by increase temperature and humidity of the vaginal and hence may provide a more favourable environment for the growth of the organisms.However, other investigators have contrary reports $(13,14)$. Our studyshowed that previous vaginal infection was significantly associated $(p=0.004)$ with the occurrence of VC.In line with prior studies $(8,22$, 23 , 24), recent use of antibioticsand oral contraceptives wereinsignificantly associated with VC. Nevertheless, antimicrobials tend todeplete the protective vaginal bacterial flora that normally keeps yeast in balance, hence the yeast overgrows and causes VC, meanwhile oral contraceptives are associated with increase oestrogen levels resulting in high glycogen in vaginal lining, a substrate on which $C$. albicans thrives $(8,23)$.Contrary to other studies douching (12)and previous treatment for $\mathrm{VC}$ were negatively correlated with the prevalence of VC but agrees with others reports(27)where no relationship existed between douching and VC.

In conclusion, this study demonstrated a high prevalence of VC among the study participants with previous vaginal infection being an important predictor of VC reoccurrence.Candida albicans continue to be the predominant species while the best antifungal treatment option in this locality is clotrimazole.

\section{Acknowledgement}

Many thanks, to the students who took part in this survey.

2. Ilkit M, Guzel AB. The epidemiology, pathogenesis, and diagnosis of vulvovaginal candidosis: a mycological perspective. Crit Rev Microbiol. 2011;37(3):250-61.

3. Fidel PL, Cutright J, Steele C. Effects of reproductive hormones on experimental vaginal candidiasis. Infect Immun. 2000;68(2):651-7.

4. Nwadioha SI, Bako IA, Onwuezobe I, Egah DZ. Vaginal trichomoniasis among HIV 
patients attending primary health care centers of Jos, Nigeria. Asian Pacific J Trop Dis. 2012;2(5):337-41.

5. Asticcioli S, Sacco L, Daturi R, Matti C, Nucleo E, Zara F, et al. Trends in frequency and in vitro antifungal susceptibility patterns of Candida isolates from women attending the STD outpatients clinic of a tertiary care hospital in Northern Italy during the years 2002-2007. New Microbiol. 2009;32:199-204.

6. Rathod SD, Klausner JD, Krupp K, Reingold AL, Madhivanan $P$. Epidemiologic features of vulvovaginal candidiasis among reproductive-age women in india. Infect Dis Obstet Gynecol. 2012;2012.

7. Sobel JD, Faro S, Force RW, Foxman B, Ledger WJ, Nyirjesy PR, et al. Vulvovaginal candidiasis: Epidemiologic, diagnostic, and therapeutic considerations. Am J Obstet Gynecol. 1998;178(2):203-11.

8. Faro S. Sexually transmitted diseases. Compr Ther. 1998;24(2):78-85.

9. Hester RA, Kennedy SB. Candida infection as a risk factor for HIV transmission. J Women's Heal. 2003;12(5):487-94.

10. Barousse MM, Van Der Pol BJ, Fortenberry D, Orr D, Fidel PL. Vaginal yeast colonisation, prevalence of vaginitis, and associated local immunity in adolescents. Sex Transm Infect. 2004;80(1):48-53.

11. Elegbe IA, Elegbe I. Quantitative relationships of Candida albicans infections and dressing patterns in Nigerian women. Am J Public Health. 1983;73(4):450-2.

12. Ekpenyong $\mathrm{CE}$, Inyang-etoh EC, Ettebong EO, Akpan UP, Ibu JO, Daniel NE. Recurrent vulvovaginal candidosis among young women in south eastern Nigeria: the role of lifestyle and health-care practices. International Journal of STD \& AIDS. 2012. p. 704-9.

13. Otero L, Palacio V, Carreño F, Méndez FJ, Vázquez F. Vulvovaginal candidiasis in female sex workers. Int J STD AIDS. 1998;9(9):526-30.

14. Mårdh P-A, Rodrigues AG, Genç M, Novikova N, Martinez-de-Oliveira J, Guaschino S. Facts and myths on recurrent vulvovaginal candidosis--a review on epidemiology, clinical manifestations, diagnosis, pathogenesis and therapy. International journal of STD \& AIDS. 2002. p. 522-39.

15. Elegbe IA, Botu M. A preliminary study on dressing patterns and incidence of candidiasis. Am J Public Health. 1982;72(2):176-7.

16. Cheesbrough M. District laboratory practice in tropical countries [Internet]. 2nd editio.
Vasa. Cambridge, New York, Melbourne, Madrid, Cape Town, Singapore, São Paulo Cambridge: Cambridge University Press The Edinburgh Building, Cambridge CB2 8RU, UK Published; 2006 [cited 2013 Jul 31]. Available from: http:/ / medcontent.metapress.com/index/ A65RM03P4874243N.pdf

17. Pirotta M V., Garland SM. Genital candida species detected in samples from women in Melbourne, Australia, before and after treatment with antibiotics. J Clin Microbiol. 2006;44(9):3213-7.

18. Seddigheh Esmaeilzadeh, Saeid Mahdavi Omran ZR. Frequency and Etiology of Vulvovaginal Candidiasis in Women Referred to a Gynecological Center in Babol, lran. Royan Institue Int J Fertil Steril. 2009;3(2):74-7.

19. Consolaro MEL, Albertoni TA, Svidzinski AE, Peralta RM, Svidzinski TIE. Vulvovaginal candidiasis is associated with the production of germ tubes by Candida albicans. Mycopathologia. 2005;159(4):5017.

20. Sonnex C, Lefort W. Microscopic features of vaginal candidiasis and their relation to symptomatology. Sex Transm Infect. 1999;75(6):417-9.

21. Makela P, Leaman D, Sobel JD. Vulvovaginal trichosporonosis. Infect Dis Obstet Gynecol. 2003;11(2):131-3.

22. Hazen KC. New and emerging yeast pathogens. Clinical Microbiology Reviews. 1995. p. 462-78.

23. Mathema B, Cross E, Dun E, Park S, Bedell J, Slade B, et al. Prevalence of vaginal colonization by drug-resistant Candida species in college-age women with previous exposure to over-the-counter azole antifungals. Clin Infect Dis. 2001;33(5):E237.

24. Auger P, Joly J. Microbial flora associated with Candida albicans vulvovaginitis. Obstet Gynecol. 1980;55(3):397-401.

25. Spinillo A, Capuzzo E, Nicola S, Baltaro F, Ferrari A, Monaco A. The impact of oral contraception on vulvovaginal candidiasis. Contraception. 1995. p. 293-7.

26. Nwadioha S, Egah D, Banwat E, Egesie J, Onwuezobe I. Prevalence of bacterial vaginosis and its risk factors in HIV/AIDS patients with abnormal vaginal discharge. Asian Pac J Trop Med. Elsevier( Singapore) Pte Ltd.; 2011;4(2):156-8.

27. Martino JL, Youngpairoj S, Vermund SH. Vaginal douching: personal practices and public policies. J Womens Health (Larchmt). 2004;13(9):1048-65. 